\title{
RACE IS NOT PATHOLOGICAL BUT RACISM IS
}

\author{
RAÇA NÃO É PATOLÓGICA, MAS O RACISMO É
}

\section{RAZA NO ES PATOLÓGICA, PERO EL RACISMO ES}

\author{
Dzifa Dordunoo ${ }^{1}$
}

How to cite this article: Dordunoo D. Race is not pathological bur racism is. Rev baiana enferm. 2020;34:e34990.

Objectives: To provide a brief history of the race variable, to discuss the misuse of race as a biological rather than a social construction and its implications for the practice of nursing and to suggest racism as a primary determinant of health among people of African descent. Method: Critical reflection on the concept of race and racism. Results: Racism has not changed over the years, but its unit of measurement: race has evolved. Conclusion: It is important to explore the history of the race to understand that African descent has little to do with the physical and mental health profile of black people. The inconsistencies in the classification of people of the same species across countries do not remove the social implications of racism, because the notion of inequality is implicit in racial groups. Thus, disparities in social determinants of health tend to continue and worsen for people of African descent.

Descriptors: Race. Racism. Nursing. Health.

Objetivos: Fornecer uma breve história da variável raça, discutir o uso incorreto da raça como uma construção biológica em vez de social e suas implicações para a prática da enfermagem e sugerir o racismo como determinante primário da saúde entre as pessoas de ascendência africana. Método: Reflexão crítica sobre a concepção de raça e racismo. Resultados: O racismo não mudou ao longo dos anos, mas a sua unidade de medida: raça evoluiu. Conclusão: É importante explorar a história da raça para entender que a ascendência africana tem pouco a ver com o perfil de saúde física e mental de pessoas negras. As inconsistências na classificação de pessoas da mesma espécie entre os países não tiram as implicações sociais do racismo, porque a noção de desigualdade está implícita nos grupos raciais. Assim, as disparidades nos determinantes sociais da saúde tendem a continuar e piorar para as pessoas de descendência africana.

Descritores: Raça. Racismo. Enfermagem. Saúde.

Objetivos: proporcionar una breve historia de la variable raza, discutir el mal uso de la raza como una construcción biológica más que social y sus implicaciones para la práctica de la enfermería y sugerir el racismo como un determinante principal de la salud entre las personas de ascendencia africana. Método: Reflexión crítica sobre el concepto de raza y racismo. Resultados: el racismo no ba cambiado con los años, pero su unidad de medida: la raza ha evolucionado. Conclusión: es importante explorar la bistoria de la raza para comprender que la ascendencia africana tiene poco que ver con el perfil de salud física y mental de las personas negras. Las inconsistencias en la clasificación de las personas de la misma especie en todos los países no eliminan las implicaciones sociales del racismo, porque la noción de desigualdad está implícita en los grupos raciales. Por lo tanto, las disparidades en los determinantes sociales de la salud tienden a continuar y empeorar para las personas de ascendencia africana.

Descriptores: Raza. Racismo. Enfermería. Salud.

Nurse. Doctor in Philosophy in Nursing. Assistant Professor at University of Victoria. Victoria, British Columbia, Canada. dzifa@uvic.ca http://orcid.org/0000-00020290-8261. 


\section{Introduction}

Race is used very frequently in health literature however researchers rarely define the term nor do they explain the possible reasons for why the differences exist between the racial groups ${ }^{(1)}$. It is often operationalized in research as skin colour alone i.e. black, white; while other times it is classified as skin colour and/or ancestral origin i.e. black/African-American ${ }^{(2-3)}$. The conundrum about what race represents in health literature arises mainly because: it lacks a standardized conceptual and operational definitions, it is a socially constructed variable often used as a proxy for biological predispositions; and the inconsistent ways it is operationalized in research; specifically is race skin colour alone, is it ancestry, ethnicity or all of the above? If all of the above, what are the skin colours of all the various racial categories or why are some groups classified by skin colour while others are referred to by ancestry (i.e. Chinese) or geographical area of origin (i.e. indigenous)? Researchers do not address these questions in the research reports. The silence leads many in healthcare including nurses to conclude that the differences arise from biological predeterminations.

The assumption might follow that if skin colour is driven by melanin - a biological process - which is common among people of African descent then the biological interpretation of race holds that there are other biological processes unique to this group as central to the differences in health outcomes. Despite warning from various associations, this practice in health and scientific communities lend support to the long held believe that race is a biological construct that underline differences in health outcomes $^{(4,5,6)}$. The unintended consequence of this reasoning is clinicians can forgo exploring contextual, modifiable factors that predispose people to poor health outcomes ${ }^{(4)}$. At the personal level, people can often become resolved to the notion that their bodies are wired in a particular way that results in poor health. This view has some truth to it but not for the reasons many might think.
In this reflection, I defend the idea that race itself is not pathological - that is, race does not make people sick. Racism - the negative experiences of social inequalities because of biases related to anthropological differences that makes people sick.

This is a critical reflection on race and racism that aims to: Provide a brief history of the race variable, discuss the misuse of race as a biological rather than a social construction and its implications for nursing practice and suggest racism as a primary determinant of health among people of African descent.

\section{Result and Discussion}

The experiences of black "race" in the United States of America (USA) is perhaps the most documented in the health literature. An issue that unifies this group of people in the USA is their shared experiences of racism and discrimination in their communities, places of work, while interacting with healthcare workers and law enforcement personnel to name a few ${ }^{(7)}$. The impacts of these experiences on health are complex but simply put there is an association between racism experienced by Americans of African descent and polygenic physical diseases like cardiovascular diseases and mental health conditions such as depression ${ }^{(8)}$. Evidence also indicates heterogeneity among the health profiles of people of African descent living in the various parts of the world - those in the USA having a poorer health profiles than their counterparts elsewhere in the world ${ }^{(9)}$. It is thus important to explore the history of race in this context to understand that African ancestry has little to do with the physical and mental health profile of people classified globally as black; but more to do with their experiences in societies that has placed greater negative value on their skin colour than their characters and contributions to the social fabric of their communities.

The concept of race in health research and its hierarchical order of humankind can be traced 
back to the early works of scientists like Charles Darwin. In his seminal work about the "Descent of man", Darwin like others of his time wrestled with the questions about the origin of man whether the races of man evolved from a single or different entity ${ }^{(10)}$. In that era, the anthropological differences in physical appearance, culture, social relationships and environment formed the basis of race. Ultimately the question scientists were trying to answer was whether the anthropological differences - referred to as race - support one species theory of humankind or whether these differences represent separate human species. The mapping of the human genome centuries later answered this question - there is only one odern human species ${ }^{(5)}$. The genetic evidence suggests classifying people by anthropological differences such as skin colour (i.e. black, yellow, white) or skin colour and ancestry (i.e. black/African) as a proxy for a biological commonality among people is meaningless. In fact there is a greater genetic diversity among the group classified as black than other racial groups ${ }^{(5)}$.

If the biological use of race is meaningless then what is the social use of race and its implications for health outcomes research. The scientific community during Darwin's time planted an insidious idea of racial superiority known as scientific racism - in its pursuit to answer questions about the human species. The prevailing idea was that the observed anthropological differences, i.e. race, made some people superior. Conceptually, race became the unit of measure on the racism scale which illustrated the perceived value of people within a society. This ideology permeated the social fabric to form the basis for some of the worst atrocities against humanity. For example, in the Americas this ideology justified the social system of denying basic human rights to people of African origin, whose darker skin complexion - an anthropological difference - supposedly made them inferior to their lighter complexion counterparts of European descent.

Racism has not changed over the years - but as reflected in its unit of measure race - it has evolved overtime. Race originally appeared on the 1790 census in the USA, over two centuries after the north American slave trade began in the $1500 \mathrm{~s}^{(11)}$. It had three options white, slave or other. In the years following the legal abolishment of slavery, the options expanded to include free, colored, mulatto, negro, black and African American. Nowadays, race in USA is categorized as American Indian (Alaska Native), Asian, black (African American), Hispanic (Latino), Native Hawaiian (other, Pacific Islander) and white $^{(12)}$. Similarly, the Canadian census uses the following categories: black, white, South Asian, Chinese, Filipino, Latin American, Arab, Southeast Asian, west Asian, Korean, Japanese, others ${ }^{(13)}$. In the United Kingdom, people are broadly classified by colour and others by ancestry; i.e. black, white, Asian, Mixed and other; whilst in Brazil people are classified as indigenous, white, black and yellow ${ }^{(14)}$.

The inconsistencies in classifying people of same species across countries do not take away from the social implications of racism because implicit in the racial groups is the notion of inequality. These inequalities form the basis for structural violence which underpin the social determinants of health affecting the health profiles of people of African descent ${ }^{(15)}$. It is important to note that the disparities in the social determinants of health are critical to health but they are symptoms of a larger problem - which is racism. Thus until this can be truly addressed, disparities in social determinants of health will continue and worsen for people of African descents but will increasingly expand to include other groups.

Evidence of this expansion is noted in recent studies from Canada that show an association between higher reports of discrimination and chronic disease rates among indigenous people and those of African descent ${ }^{(16)}$. The impact of these experiences are reflected in social determinants of health with indigenous people in Alberta and Canada earned less money, have higher unemployment rates and were more likely to have poor access to housing and education ${ }^{(17)}$. 
Moreover, field experiment exploring impact of discrimination on hiring practices in Europe and North America found discrimination occurred in all the nine countries studied with whites receiving more call-backs than non-whites ${ }^{(18)}$. Interestingly, this study also found that there was discrimination against white immigrants although it was at a lower rate than seen with non-white groups ${ }^{(19)}$. Injustices - like racism - know no boundaries. Thus confronting it at the earliest occurrence is society's biggest defence. Without which, the devastating effects will be felt not just within the African descent communities but in any community where differences exist.

In our modern day societies particularly in north America, where the laws of the land were created without the current demographics in mind, the original ideology of race remain embedded in our consciousness. Colonization and imperialism created racist laws to purposefully subjugate one or more groups against one dominant group. It is thus the practice of racism that is the main risk factor impacting health. When used in research, the social implications of racism ought to be reported with a degree of transparency and objectivity to allow the consumer of the research to decipher how to integrate the research findings into clinical practice.

\section{Nursing implications}

As a doctoral prepared nurse and black, my interest in the concept of race occurred later in my academic journey. It wasn't until beginning of my doctoral studies when I was preparing an abstract on heart failure did I began to question the validity of race. As I progress in my studies, I found in my dissertation that race was not a significant predictor of 30-day hospital readmission $^{(19)}$. This was surprising because all the literature showed higher readmission rates for blacks/African American. Years after defending my dissertation, I sought to better understand this concept of race.

I realized that even I had erroneously thought of race as a biological concept but my experience through the research process made me question the validity of this variable and I noted during data collection discrepancies in the classifications of the patients. Some of the people were classified as white in the demographic page of the medical records; whilst in the clinicians' notes they were described as Philipino or Asian. Others were classified as black even though they were of a mixed background. The inconsistencies highlight the general confusion about the concept, its classifications, and hint at the validity of research findings using this concept.

In nursing schools, most students are exposed to health literature and textbooks that note race as a risk factor for many diseases. It is important for students and practicing nurses to know that when race appears as a significant predictor of health outcomes, this represents the culminated effects of racism. For example, race is often noted as a risk factor for diabetes mellitus type II. People are predisposed to this disease largely because of lifestyle, environmental and behavioural factors ${ }^{(20)}$. Factors such as overnutrition, physical inactivity, hypoxia, psychological stress and environmental pollutants trigger a cascade of events that hinder insulin responsiveness at the cellular level leading to insulin resistance ${ }^{(21)}$.

Insulin resistance is largely believed to be responsible for the pathogenesis of diseases such as diabetes mellitus and cardiovascular diseases to name a few ${ }^{(21)}$. Since racism is associated with factors hat are also linked with insulin resistance, it can be postulated that it has more effects on the development and outcome of such diseases than genes alone. This is not to say genes do not play a role in the pathophysiology of diabetes mellitus type II however the identified genes by themselves are insufficient - it merely suggests that under the similar societal conditions the chance of the disease development is high for all people from different backgrounds. As noted earlier injustices like racism have no boundaries so while racism may underlie the health profile of people from African descent, it is not the only injustice that has this potential.

Shifting the thinking about what race really means in our societies would urge researchers 
and clinicians to consider ways to ameliorate the daily experiences of racism and potentially improve health outcomes of those of African and other ancestral descents that face marginalization.

Ultimately in health outcomes research involving polygenic diseases, the use of race conflates being black as a risk factor it suggests being black as the independent factor influencing the outcomes reinforcing the centuries old misconceptions about race. When race appears significant in health research, it indicates that racism and its societal inequalities - i.e. disparities in social determinants of health disproportionately affect that group, increasing their exposure to risk factors for that disease.

In this context, race is not the risk factor that makes people sick but the experiences people endure because of racism can have negative effects on their health leading to diseased states and poorer health outcomes. The empirical effects of these experiences are depicted in the concept of biological weathering and surfacing in the field of epigenetics ${ }^{(22-25)}$.

The implications for nursing practice were discussed, considering that since nurses seek to use evidence for our practices, we need to be aware of this when reading research that presents race as a significant predictor of health outcomes. Considering that these findings should be alarming to all of us, as it is an indication of racism and should lead us to seek interventions to eliminate unfair treatment for these people.

\section{Conclusion}

Nurses are the largest group of health professionals and clinical professionals closest to patients and we describe evidence from several fields, including social and biological sciences, to support our practices. Thus, it is important that we understand what "race" means in the research findings, in order to translate the evidence to inform the practice. Nurses need to be aware that race has no biological basis and its meaning in research is indicative of racism - the societal experiences of being born with particular anthropological features.
As nurses, we must transmit to the people we encounter in our practice, the insidious nature of racism, validating their experiences and exploring with them ways that can mitigate the structural violence they face on a daily basis. Nursing is the "care profession" and our goal as nursing researchers is to conduct studies that detect significant "care" interventions in order to combat the effects of racism on health.

So, as research consumers, the next time you read a survey that identifies "race" as a significant predictor, check to see if the authors explored the effects of racism on the population studied and described interventions that can reduce the observed differences.

\section{Colaborations:}

1 - conception, design, analysis and interpretation of data: Dzifa Dordunoo.

2 -writing of the article and relevant critical review of the intellectual content: Dzifa Dordunoo.

3 - final approval of the version to be published: Dzifa Dordunoo.

\section{References}

1. Lee C. "Race" and "ethnicity" in biomedical research: How do scientists construct and explain differences in health? Soc Sci Med [Internet] 2009 Mar [cited 2017 Aug 22];68(6):1183-90. Available from: http://linkinghub.elsevier.com/ retrieve/pii/S0277953608006795

2. Goyal P, Paul T, Almarzooq ZI, Peterson JC, Krishnan U, Swaminathan RV, et al. Sex-and racerelated differences in characteristics and outcomes of hospitalizations forheart failure with preserved ejection fraction. J Am Heart Assoc. 2017;6(4).

3. Moayedi Y, Fan CPS, Miller RJH, Tremblay-Gravel M, Posada JGD, Manlhiot C, et al. Gene expression profiling and racial disparities in outcomes after heart transplantation. J HearLung Transplant [Internet]. 2019;38(8):820-9. Available from: https://doi.org/10.1016/j.healun.2019.05.008

4. Cooper RS, Kaufman JS, Ward R. Race and genomics. N Engl J Med. 2003;348(12):1166-70.

5. Olson S, Berg K, Bonham V, Boyer J, Brody L, Brooks L, et al. The use of racial, ethnic, and 
ancestral categories in human genetics research. Am J Hum Genet. 2005;77(4):519-32.

6. Yudell M, Roberts D, DeSalle R, Tishkoff S. Science and society: Taking race out of human genetics. Science (80-). 2016;351(6273):564-5.

7. National Public Radio, Robert Wood Johnson Foundation, Harvard T. H. Chan School of Public Health. Discrimination in America: Experiences and views of African Americans [Internet]. Boston (MA); 2017 Oct. [cited 2018 Feb 22]. Available from: https://www.npr.org/assets/img/2017/10/23/ discriminationpoll-african-americans.pdf

8. Paradies Y, Ben J, Denson N, Elias A, Priest N, Pieterse A, et al. Racism as a determinant of health: A systematic review and meta-analysis. PLoS One. 2015;10(9):1-48.

9. Williams DR, Priest N, Anderson NB. Understanding associations among race, socioeconomic status, and health: Patterns and prospects. Heal Psychol.2016;35(4):407-11.

10. Darwin, C. The Descent of Man, and selection in relation to sex [Internet]. New York: D. Appleton and Company; 1889 [cited 2018 Feb 18]. Available from: http://darwin-online.org.uk/converted/pdf/ 1889_Descent_F969.pdf

11. Best LE, Chenault J. Racial Classifications, Biomarkers, and the Challenges of Health Disparities Research in the African Diaspora. J Pan Afr Stud [Internet]. 2014 Jun [cited 2018 Jan 20];7(1):74-98. Available from: https://www.ncbi.nlm.nih.gov/pmc/articles/ PMC6162056/

12. National Institution of Health. Racial ethnic categories and definitions for NIH diversity Programs and for Other Reporting Purposes [Internet]. Bethesda (USA); 2015 [cited 2018 Jan 30]. Available from: https:/grants.nih.gov/grants/ guide/notice-files/not-od-15- 089.html

13. Statistics Canada. Visible minority and population group reference guide, census of population, 2016 [Internet]. Canadá: 2017 Oct [cited 2018 Jan 14]. Available from: https://www12.statcan.gc.ca/ census-recensement/2016/ref/guides/006/98-500x2016006-eng.pdf

14. Fry, P. The politics of racial classification in Brazil [internet]. 2009. Available from: https://journals. openedition.org/jsa/11108

15. Farmer PE, Nizeye B, Stulac S, Keshavjee S. Structural violence and clinical medicine. PLoS Med. 2006;3(10):1686-91.
16. Siddiqi A, Shahidi FV, Ramraj C, Williams DR. Associations between race, discrimination and risk for chronic disease in a population-based sample from Canada. Soc Sci Med [Internet]. 2017;194(December 2016):135-41. Available from: https://doi.org/10.1016/j.socscimed.2017.10.009

17. Kolahdooz, F, Forouz, N, Yi, J, Sharma, S. Understanding the social determinants of health among Indigenous Canadians: priorities for health promotion policies and actions. Glob Health Action [Internet]. 2015;8:27968. Available from: http://www.embase.com/search/s?subaction=vie wrecord\&from=export\&id=L615603392\%0Ahttp:// dx.doi.org/10.3402/gha.v8.27968

18. Quillian L, Heath A, Pager D, Midtbøen A, Fleischmann F, Hexel O. Do Some Countries Discriminate More than Others? Evidence from 97Field Experiments of Racial Discrimination in Hiring. Sociol Sci. 2019;6:467-96.

19. Dordunoo D, Thomas SA, Friedmann E, Russell SD, Newhouse RP, Akintade B. Inpatient Unit Heart Failure Discharge Volume Predicts All-cause 30-Day Hospital Readmission. J Cardiovasc Nurs. [Internet]. 2017; 32(3): 218-25. Available from: https://doi.org/10.1097/ JCN.0000000000000331

20. Wu Y, Ding Y, Tanaka Y, Zhang W. Risk factors contributing to type 2 diabetes and recent advances in the treatment and prevention. Int $\mathrm{J}$ Med Sci. 2014;11(11):1185-200.

21. Onyango AN. Cellular Stresses and Stress Responses in the Pathogenesis of Insulin Resistance. Oxid Med Cell Longev. 2018;2018.

22. Smedley BD. The lived experience of race and its health consequences. Am J Public Health. 2012;102(5):933-5.

23. Walker, RJ, Williams JS, Egede LE. Influence of race, ethnicity and social determinants of health on diabetes outcomes. Am J Med Sci. 2016;351(4), 366-373

24. Simons RL, Lei MK, Beach SR, Philibert RA, Cutrona CE, Gibbons FX, et al. Economic hardship and biological weathering: The epigenetics of aging in a U. S. sample of black women. Soc Sci Med.2016;150:192-200.

25. Geronimus AT. Deep integration: Letting the epigenome out of the bottle without losing sight of the structural origins of population health. Am J Public Health.2013;103(SUPPL.1):56-63. 
Received: December 27, 2019

Approved: March 11, 2020

Published: May 13, 2020

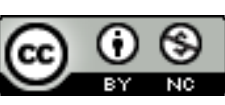

The Revista Baiana de Enfermagem use the Creative Commons license - Attribuition -NonComercial 4.0 International. https://creativecommons.org/licenses/by-nc/4.0/

This article is an Open Access distributed under the terms of the Creative Commons (CC BY-NC). This license lets others remix, adapt and create upon your work to non-commercial use, and although new works must give its due credit and can not be for comercial purposes, the users do not have to license such derivative works under the same terms. 